\section{Kidney \\ Blood Pressure \\ Research}

Kidney Blood Press Res 2012;36:149-161

\begin{tabular}{l|l} 
DOI: $10.1159 / 000343405$ & C 2012 S. Karger AG, Basel
\end{tabular}

Published online: October 26, 2012

www.karger.com/kbr

149

Accepted: October 15, 2012

Original Paper

\title{
OSR1-Sensitive Renal Tubular Phosphate Reabsorption
}

\author{
Ganesh Pathare Michael Föller $^{\mathrm{a}} \quad$ Arezoo Daryadel $^{\mathrm{b}} \quad$ Kerim Mutig $^{\mathrm{c}}$ \\ Evgeny Bogatikov ${ }^{a} \quad$ Abul Fajol $^{\mathrm{a}} \quad$ Ahmad Almilaji $^{\mathrm{a}} \quad$ Diana Michael $^{\mathrm{a}}$ Gerti Stange $^{\mathrm{b}}$ \\ Jakob Voelkla Carsten A. Wagner ${ }^{\mathrm{b}}$ Sebastian Bachmann ${ }^{\mathrm{c}, d} \quad$ Florian Lang ${ }^{\mathrm{a}, \mathrm{d}}$ \\ aDepartment of Physiology, University of Tübingen, Gmelinstr. 5, D-72076 Tübingen, Germany, \\ Institute of Physiology and Zurich Center for Integrative Human Physiology, University of Zurich, \\ Winterthurerstraße 190, 8057 Zürich, Switzerland, Institut für Vegetative Anatomie, Charitéplatz 1 , \\ D-10117 Berlin, Germany, ${ }^{\mathrm{d}}$ contributed equally and thus share last authorship
}

\section{Key Words}

$\mathrm{Na}^{+}$- Phosphate cotransporter - FGF23 - Bone density - Proximal tubule • Oxidative stressresponse kinase

\begin{abstract}
Background: The oxidative stress-responsive kinase 1 (OSR1) participates in the WNK-(with no K) kinase dependent regulation of renal salt excretion and blood pressure. Little is known, however, about the role of OSR1 in the regulation of further renal transport systems. The present study analyzed the effect of OSR1 on NaPiIIa, the major renal tubular phosphate transporter. Methods: Immunohistochemistry and confocal microscopy were employed to determine renal localization of OSR1 and NaPiIIa. To elucidate the effect of OSR on NaPiIIa activity, cRNA encoding NaPiIIa was injected into Xenopus oocytes with or without additional injection of CRNA encoding OSR1, and phosphate transport was estimated from phosphateinduced currents determined with dual electrode voltage clamp. To elucidate the in vivo significance of OSR1 serum phosphate and hormone concentrations as well as urinary phosphate output of mice carrying one allele of WNK-resistant OSR1 (osr $1^{\text {tg/+ }}$ ) were compared to the respective values of wild type mice $\left(\mathrm{Osr}^{+/+}\right)$. Results: NaPiIIa and OSR1 were both expressed in proximal renal tubule cells. Coexpression of OSR1 significantly up-regulated phosphate-induced currents in NaPiIIa-expressing Xenopus oocytes. Despite decreased serum phosphate concentration urinary phosphate excretion was significantly increased and NaPiIIa protein abundance in the brush border membrane significantly reduced in osr $1^{\text {tg/+ }}$ mice as compared to $\mathrm{osr}^{1^{+/+}}$mice. Serum PTH and calcitriol levels were similar in osr $1^{\text {tg/+ }}$ mice and in osr $1^{+/+}$mice, serum FGF23 concentration was, however, significantly higher in osr $1^{\text {tg/+ }}$ mice than in $\mathrm{osr}^{+/+}$mice. Conclusions: OSR1 is expressed in proximal renal tubules and participates in the regulation of FGF23 release and renal tubular phosphate transport.
\end{abstract}

Copyright $\odot 2012$ S. Karger AG, Basel

Florian Lang

Department of Physiology, University of Tübingen

Gmelinstr. 5, D-72076 Tübingen (Germany)

Tel. +49-7071-2972194, Fax+49-7071-295618, E-Mail florian.lang@uni-tuebingen.de 


\section{Kidney Blood Pressure Research}

Kidney Blood Press Res 2012;36:149-161

\begin{tabular}{l|l}
\hline DOI: $10.1159 / 000343405$ & C 2012 S. Karger AG, Basel
\end{tabular}

Published online: October 26, 2012

www.karger.com/kbr

Pathare/Föller/Daryadel et al.: OSR1-Sensitive Pi Transport

\section{Introduction}

The oxidative stress-responsive kinase 1 (OSR1) participates in the signaling regulating transport during oxidative and osmotic stress [1-6]. OSR1 is activated by the osmosensitive WNK (with no K) kinase isoforms WNK1 and WNK4 [3, 7, 8] and up-regulates the thiazidesensitive $\mathrm{Na}^{+}-\mathrm{Cl}^{-}$cotransporter (NCC) and the furosemide-sensitive $\mathrm{Na}^{+}, \mathrm{K}^{+}, 2 \mathrm{Cl}^{-}$cotransporters (NKCC1 and NKCC2), thus contributing to the regulation of cell volume, transepithelial transport, renal salt excretion, and GABA neurotransmission [1-3, 9-14]. Presumably due to their impact on renal tubular salt transport WNK1 and WNK4 [2, 15-18] as well as OSR1 [7, 19-22] participate in the regulation of blood pressure.

Nothing is known about a role of OSR1 in other nephron segments and in the regulation of other renal tubular transport systems. The present study thus explored whether OSR1 influences the activity of the $\mathrm{Na}^{+}$-coupled phosphate transporter NaPiIla (SLC34A1), which is the most important carrier accomplishing renal tubular phosphate transport across the apical brush border membrane of proximal renal tubules [23-25]. Renal tubular phosphate reabsorption is tightly regulated by dietary phosphate intake, acid-base status, parathyroid hormone, 1,25- $(\mathrm{OH})_{2}$ vitamin $\mathrm{D}_{3}$, FGF23, insulin and insulin-like growth factor IGF1 [26-32]. Signaling known to regulate NaPiIIa includes the protein kinases A and C, ERK1/2, Klotho and the PI3K/PKB/GSK3 kinase cascade [33-40].

The present study addressed the putative role of OSR1 in the regulation of NaPiIIa. Coexpression of OSR1 enhanced phosphate-induced currents reflecting electrogenic phosphate transport in NaPiIIa-expressing Xenopus oocytes. Immunohistochemistry and confocal microscopy revealed expresssion of both, OSR1 and NaPiIIa, in proximal renal tubules. To explore the in vivo significance of OSR1-sensitive phosphate transport, experiments were performed experiments in mice carrying a mutation of OSR1 resistant to WNK-mediated activation (osr $\left.1^{t g /+}\right)$ and in the respective wild type mice $\left(o s r 1^{+/+}\right)$. The mutation compromizes OSR1 activity [19]. Urinary phosphate excretion was indeed higher and serum phosphate concentration lower in $o s r 1^{t g /+}$ mice than in $o s r 1^{+/+}$mice. Thus, the observations point to a role of OSR1 in the regulation of renal tubular phosphate transport.

\section{Materials and Methods}

\section{In vitro expression}

For generation of cRNA, constructs were used encoding wild type human NaPiIla [41] and human OSR1. The cRNA was generated as described previously [42]. The constructs encoding wild type and catalyticallyinactive ${ }^{\mathrm{D} 164 \mathrm{~A}}$ OSR1 were kindly provided by Dario Alessi (University of Dundee, UK). For electrophysiology, Xenopus oocytes were prepared as previously described $[43,44]$. Fifteen ng of NaPiIIa cRNA were injected on the first day and $10 \mathrm{ng}$ OSR1 cRNA on the second day into Xenopus oocytes. All experiments were performed at room temperature 3 days after the second injection. Two electrode voltage-clamp recordings were performed at a holding potential of $-50 \mathrm{mV}$. The data were filtered at $10 \mathrm{~Hz}$ and recorded with a Digidata A/D-D/A converter and Chart V.4.2 software for data acquisition and analysis (Axon Instruments). The control solution (superfusate / ND96) contained $96 \mathrm{mM} \mathrm{NaCl}, 2 \mathrm{mM} \mathrm{KCl}, 1.8 \mathrm{mM} \mathrm{CaCl}_{2}, 1 \mathrm{mM} \mathrm{MgCl}_{2}$ and $5 \mathrm{mM} \mathrm{HEPES}$, pH 7.4. One mM phosphate was added to induce NaPilla-dependent currents. The flow rate of the superfusion was $20 \mathrm{ml} / \mathrm{min}$, and a complete exchange of the bath solution was reached within about $10 \mathrm{~s}$.

\section{Animals}

All animal experiments were conducted according to the German law for the welfare of animals and were approved by local authorities. Blood was drawn, urine collected or tissue isolated from sex- and age-matched 3-8-month-old heterozygous OSR1 knockin mice $\left(o s r 1^{t / /+}\right)$ and respective wild type mice (osr $\left.1^{+/+}\right)$, kindly provided by Dario Alessi. As described earlier [45], in the knockin mice the T-loop Thr residue in OSR1 (Thr185) was mutated to Ala to prevent activation by WNK isoforms. Homozygous OSR1 knockin mice (osr $1^{\text {tg/tg }}$ ) are not viable [45]. Mice had free access to control diet (Ssniff, Soest, Germany) containing $7000 \mathrm{mg} / \mathrm{kg}$ phosphorus or to phosphate-depleted diet (Altromin, Lage, Germany) containing $131 \mathrm{mg} / \mathrm{kg}$ phosphate and to tap drinking 


\section{Kidney \\ Blood Pressure Research}

Kidney Blood Press Res 2012;36:149-161

\begin{tabular}{l|l}
\hline DOI: $10.1159 / 000343405$ & (c) 2012 S. Karger AG, Basel
\end{tabular}

Published online: October 26, 2012

www.karger.com/kbr

Pathare/Föller/Daryadel et al.: OSR1-Sensitive Pi Transport

water ad libitum. To obtain serum, mice were anaesthetized with diethylether (Roth, Karlsruhe, Germany) and blood was drawn into capillaries by puncturing the retrobulbar plexus.

To determine creatinine clearance, urinary flow rate and urinary excretion of phosphate, mice were placed individually in metabolic cages (Techniplast, Hohenpeissenberg, Germany) as described previously [46]. They were allowed a 2 days habituation period during which food and water intake, urinary flow rate and phosphate excretion were recorded every day to ascertain that mice were adapted to the new environment. Subsequently, $24 \mathrm{~h}$ collection of urine was performed for three consecutive days in order to obtain the urinary parameters. This procedure was repeated under low-phosphate diet. To assure quantitative urine collection, metabolic cages were siliconized, and urine was collected under water-saturated oil.

The phosphate concentration was determined colorimetrically utilizing a commercial diagnostic kit (Roche Diagnostics, Mannheim, Germany). The urinary concentration of $\mathrm{Ca}^{2+}$ was measured by flame photometry (Eppendorf, Hamburg, Germany). The creatinine concentration in urine was determined using the Jaffe reaction (Labor und Technik, Berlin, Germany). The serum intact parathyroid hormone concentration was measured using an ELISA kit (Immunotopics, San Clemante, USA). The assay sensitivity, i. e. the lowest concentration of mouse PTH which is measurable, is $4 \mathrm{pg} / \mathrm{ml}$ according to the manufacturer. The concentration of $1,25(\mathrm{OH})_{2} \mathrm{D}_{3}$ (IDS Diagnostics, Frankfurt/Main, Germany) and of FGF23 (Immunotopics) were also determined by ELISA.

Brush border membrane vesicles (BBMV) preparation and immunoblotting

BBMVs were prepared from mouse kidney cortex and outer medulla using the $\mathrm{Mg}^{2+}$ precipitation technique as described previously $[47,48]$. The total protein concentration was measured using the Bio-Rad Protein Assay kit (Bio-Rad, Hercules, CA, USA). BBMVs were stored at $-80^{\circ} \mathrm{C}$ until further use. Five micrograms of renal brush border membrane proteins were solubilized in loading buffer containing dithiothreitol (DTT) and separated on 8\% polyacrylamide gels. For immunoblotting, the proteins were transferred electrophoretically to polyvinylidene fluoride (PVDF) membranes (Immobilon-P, Millipore, Bedford, MA, USA). After blocking with 5\% milk powder in Tris-buffered saline $/ 0.1 \%$ Tween-20 for $60 \mathrm{~min}$, the blots were incubated with the primary antibodies: rabbit polyclonal anti-NaPiIIa (1:6000) [49] and mouse monoclonal anti- $\beta$-actin antibody (42 kD; Sigma, St. Louis, MO; 1:5000) either for $2 \mathrm{~h}$ at room temperature or overnight at $4^{\circ} \mathrm{C}$. Membranes were then incubated for $1 \mathrm{~h}$ at room temperature with secondary goat anti-rabbit or donkey anti-mouse antibodies 1:5000 linked to alkaline phosphatase (Promega, Mannheim, Germany) or to horseradish peroxidase (HRP) (Amersham, Freiburg, Germany). The protein signal was detected with the appropriate substrates (Millipore, Schwalbach, Germany) using the DIANA III-chemiluminescence detection system (Raytest, Straubenhardt, Germany). All images were analysed using the software Advanced Image Data Analyser AIDA, Raytest to calculate the protein of interest/ $\beta$-actin ratio.

\section{Western blotting of whole kidney}

To determine protein abundance in renal tissue, mice were anesthetized with diethylether. The kidneys were removed and immediately shock-frozen in liquid nitrogen. Renal tissue was homogenised with an electric homogenizer at $4^{\circ} \mathrm{C}$ in lysis buffer (54.6 mM HEPES; $2.69 \mathrm{mM} \mathrm{Na}_{4} \mathrm{P}_{2} \mathrm{O}_{7} ; 360 \mathrm{mM} \mathrm{NaCl} ; 10 \%$ [vol/vol] Glycerol; 1\% [vol/vol] NP40) containing phosphatase and protease inhibitors (Complete mini, Roche, Mannheim, Germany). Homogenates were clarified by centrifugation at $20000 \mathrm{~g}$ for 20 min. Total protein $(100 \mu \mathrm{g})$ was separated by SDS-PAGE (10\% Tris-Glycine), transferred to nitrocellulose membranes (Schleicher and Schuell, Dassel, Germany), blocked for $3 \mathrm{~h}$ in blocking buffer (5\% fat-free milk in Trisbuffered saline (TBS) containing $0.1 \%$ Tween), and incubated overnight with an anti Klotho antibody (kindly provided by Akiko Saito from the Kyowa Hakko Kirin Co., Ltd., Japan) (1:1.000 in 5\% fat free milk in TBS). After incubation with a horseradish peroxidase-conjugated anti-rat secondary antibody (Cell Signaling, Germany), the bands were visualized with enhanced chemiluminescence according to the manufacturer's instructions. Homogenates were also probed with a primary GAPDH (Cell Signaling) antibody as loading control. Densitometric analysis of Klotho and GAPDH was performed using Quantity One software (Bio-Rad Laboratories).

\section{Immunhistochemistry}

For immunofluorescence microscopic detection of NaPiIIa and OSR in proximal tubule immunolabeling was performed on cryostat or paraffin sections of $5 \mu \mathrm{m}$ thickness, blocked with $5 \%$ milk powder in PBS, 


\section{Kidney Blood Pressure Research}

Fig. 1. Distribution of the oxidative stress responsive kinase 1 (OSR1) in wild type $\left(o s r 1^{+/+}\right)$ kidneys. A. Confocal images showing double-labeling of oSR1 (green signal) and NaPiIla (red signals) in proximal tubules from wild type kidneys. Merged images demonstrate localization of OSR1 in close proximity of NaPilla in a subset of proximal tubules, whereas some proximal tubules express

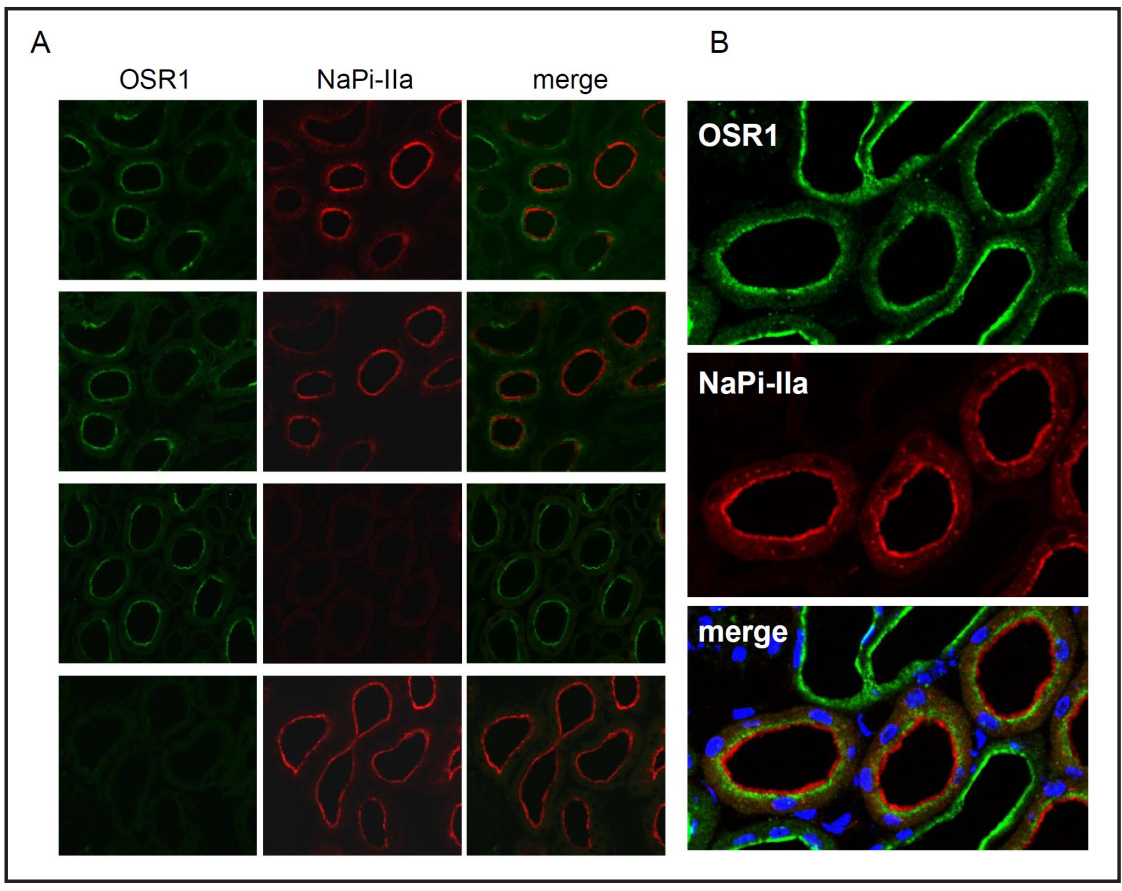

either OSR1 or NaPiIIa. B. Higher resolution images demonstrating localization of OSR1 (green signal in the apical cellular compartment) in close proximity of NaPilla (red signal in the brushborder membrane) in proximal tubules from wild type kidney; nuclei are counterstained in blue on the merged image.

incubated for $2 \mathrm{~h}$ with primary antibodies (sheep anti-OSR antibody [1:500 dilution; University of Dundee] and rabbit anti-NaPiIIa [1:400 dilution; kind gift of J. Biber, Zurich]), followed by secondary antibodies (Cy3-coupled donkey-anti sheep IgG and Cy2-coupled swine-anti rabbit IgG [Dianova]). Specificity of the double-staining procedures was controlled by parallel incubation of consecutive sections, each incubated only with one single probe. Fluorescence signals were detected by confocal laser scanning microscopy (LSM 510 META; Carl Zeiss, Jena, Germany) with a Plan Neofluar 100×/1.3 oil objective [50, 51].

\section{Statistics}

Data are provided as means \pm SEM, $n$ represents the number of independent experiments. All data were tested for significance using unpaired Student's t-test or ANOVA, as appropriate. Only results with $p<0.05$ were considered statistically significant.

\section{Results}

Immunohistochemistry was employed to explore whether OSR1 is expressed in proximal renal tubules. As illustrated in Fig. 1, OSR1 protein could indeed be detected in the proximal nephron. Concomitant labelling of the proximal tubular phosphate transporter NaPiIIa revealed localization of both, the kinase and the carrier, in a subset of proximal tubule cells (Fig. 1).

To possibly disclose an effect of OSR1 on NaPiIIa, cRNA encoding NaPiIIa was injected into Xenopus oocytes with or without cRNA encoding OSR1 and electrogenic phosphate transport determined by the dual-electrode voltage-clamp technique. Addition of phosphate $(1 \mathrm{mM})$ to the bath induced only a small inward current in non-injected or water-injected Xenopus oocytes, indicating that Xenopus oocytes do not express endogeneous electrogenic phosphate transport (Fig. 2). In Xenopus oocytes expressing NaPiIIa, phosphate induced an inward current $\left(\mathrm{I}_{\mathrm{p}}\right)$ consistent with electrogenic entry of $\mathrm{Na}^{+}$together with phosphate (Fig. 


\section{Kidney Blood Pressure Research}

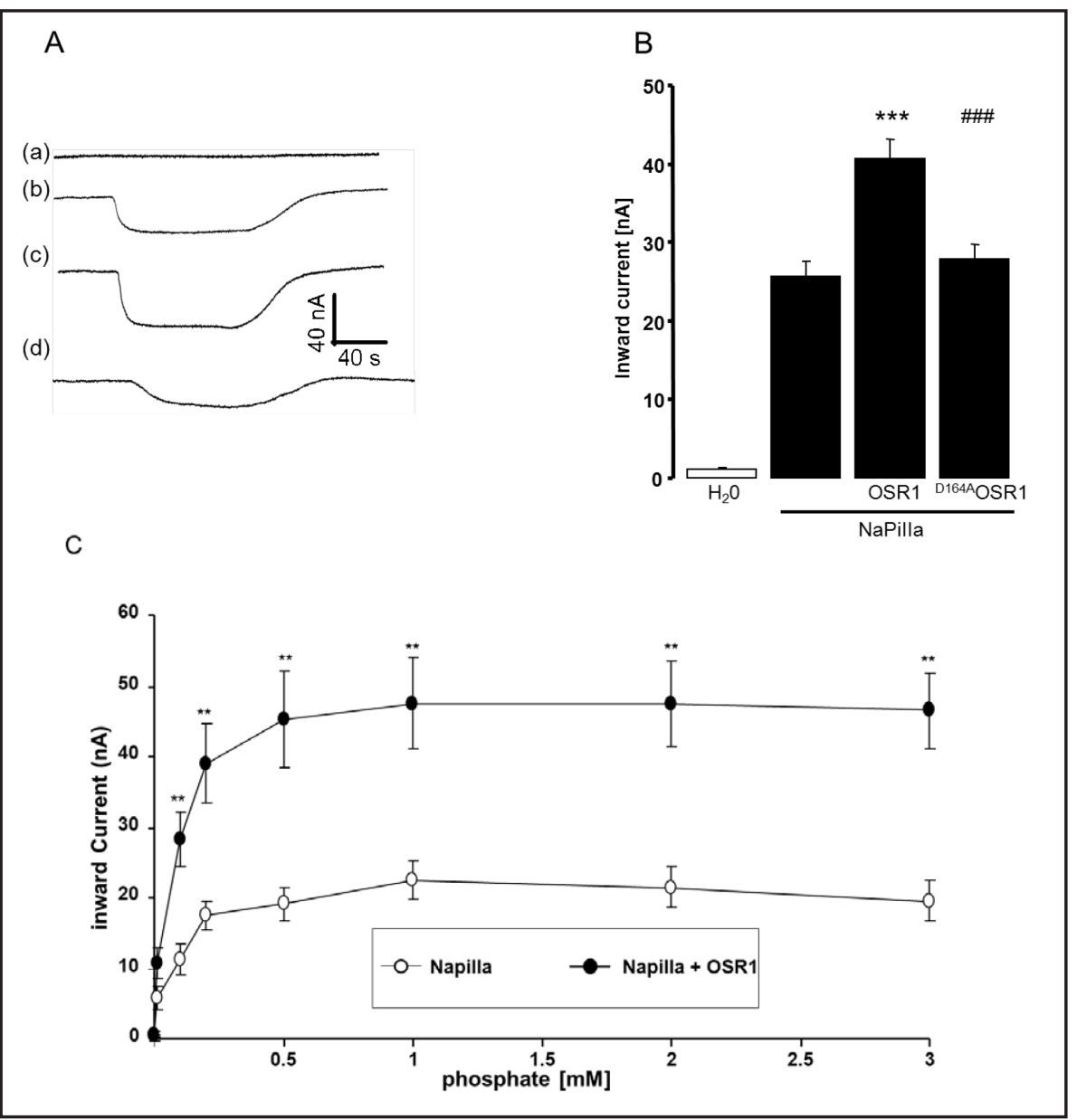

Fig. 2. Coexpression of OSR1 up-regulates electrogenic phosphate transport in NaPiIIaexpressing Xenopus oocytes. A. Representative original tracings showing phosphate (1 mM)-induced current $\left(\mathrm{I}_{\mathrm{P}}\right)$ in Xenopus oocytes injected with water (a) as well as expressing NaPiIIa without (b) or with additional coexpression of wild type OSR1(c) or inactive mutant ${ }^{\mathrm{D} 164 \mathrm{~A} O S R}$ (d). B. Arithmetic means \pm SEM $(\mathrm{n}=17-62)$ of phosphate (1 mM)-induced current $\left(\mathrm{I}_{\mathrm{p}}\right)$ in Xenopus oocytes injected with water $\left(\mathrm{H}_{2} \mathrm{O}\right)$, or expressing NaPiIla without $\left(2^{\text {nd }}\right.$ bar) or with additional coexpression of wild type OSR1 ( $3^{\text {rd }}$ bar) or of the inactive mutant ${ }^{\mathrm{D} 164 \mathrm{~A}}$ OSR 1 ( $\left.4^{\text {th }} \mathrm{bar}\right) .{ }^{* * *}(\mathrm{p}<0.001)$ indicates statistically significant difference from the absence of OSR1. \#\#\# $(\mathrm{p}<0.001)$ indicates statistically significant difference between wild type OSR1 and mutant ${ }^{\mathrm{D} 164 \mathrm{~A}}$ OSR1. C. Arithmetic means \pm SEM $(n=7)$ of $I_{p}$ as a function of phosphate concentration in Xenopus oocytes expressing NaPiIla without (open circles) or with (closed circles) additional coexpression of wild type OSR1. ${ }^{* *}(\mathrm{p}<0.01)$ indicates statistically significant difference from the absence of OSR1.

2A,B). As illustrated in Fig. 2A,B, $\mathrm{I}_{\mathrm{p}}$ was significantly enhanced by additional coexpression of OSR1. In contrast, coexpression of the inactive mutant ${ }^{D 164 A}$ OSR1 did not significantly modify $I_{p}$ in NaPilla-expressing Xenopus oocytes (Fig. 2A,B).

Fig. 2C displays a kinetic analysis of phosphate-induced current. In NaPiIla -expressing Xenopus oocytes the maximal current was $21.7 \pm 1.1 \mathrm{nA}(\mathrm{n}=7)$. The phosphate concentration required for halfmaximal current $\left(\mathrm{K}_{\mathrm{M}}\right)$ was $59.6 \pm 20.1 \mu \mathrm{M}$. The coexpression of OSR did not significantly modify apparent $\mathrm{K}_{\mathrm{M}}(55.2 \pm 9.4 \mu \mathrm{M})$, but significantly increased the maximal current to $48.8 \pm 1.2 \mathrm{nA}(\mathrm{n}=7)$. 


\section{Kidney Blood Pressure Research}

Fig. 3. Urinary phosphate excretion in $o s r 1^{+/+}$and $o s r 1^{t g /+}$ mice. Arithmetic means \pm SEM ( $n=14-16$ ) of urinary phosphate excretion in heterozygous OSR1 knockin mice (osr $1^{\text {tg/+ }}$, black bars) and wild type mice $\left(\mathrm{osr} \mathrm{I}^{+/+}\right.$, white bars) under normal diet (A) and following dietary phosphate depletion (B). * $(\mathrm{p}<0.05), \quad * *$ $(\mathrm{p}<0.01)$ indicate significant difference from $o s r 1^{+/+}$mice, \#\#\# $(\mathrm{p}<0.001)$ indicates significant difference from normal diet.

Fig. 4. Serum phosphate concentration in $o s r 1^{+/+}$and osr $1^{\mathrm{tg} / \mathrm{t}}$ mice. Arithmetic means \pm SEM $(n=14-16)$ of the serum phosphate concentration in heterozygous OSR1 knockin mice (osr $1^{\text {tg/ }}$, black bars) and wild type mice $\left(o s r 1^{+/+}\right.$, white bars) under normal diet (A) and following dietary phosphate depletion (B). * $(\mathrm{p}<0.05), * *$ $(\mathrm{p}<0.01) \quad$ indicate significant difference from osr $1^{+/+}$mice, \# $(\mathrm{p}<0.05), \# \#(\mathrm{p}<0.01)$ indicate significant difference from normal diet.
Kidney Blood Press Res 2012;36:149-161

\begin{tabular}{l|l}
\hline DOI: $10.1159 / 000343405$ & C 2012 S. Karger AG, Basel
\end{tabular}

Published online: October 26, 2012

www.karger.com/kbr

Pathare/Föller/Daryadel et al.: OSR1-Sensitive Pi Transport
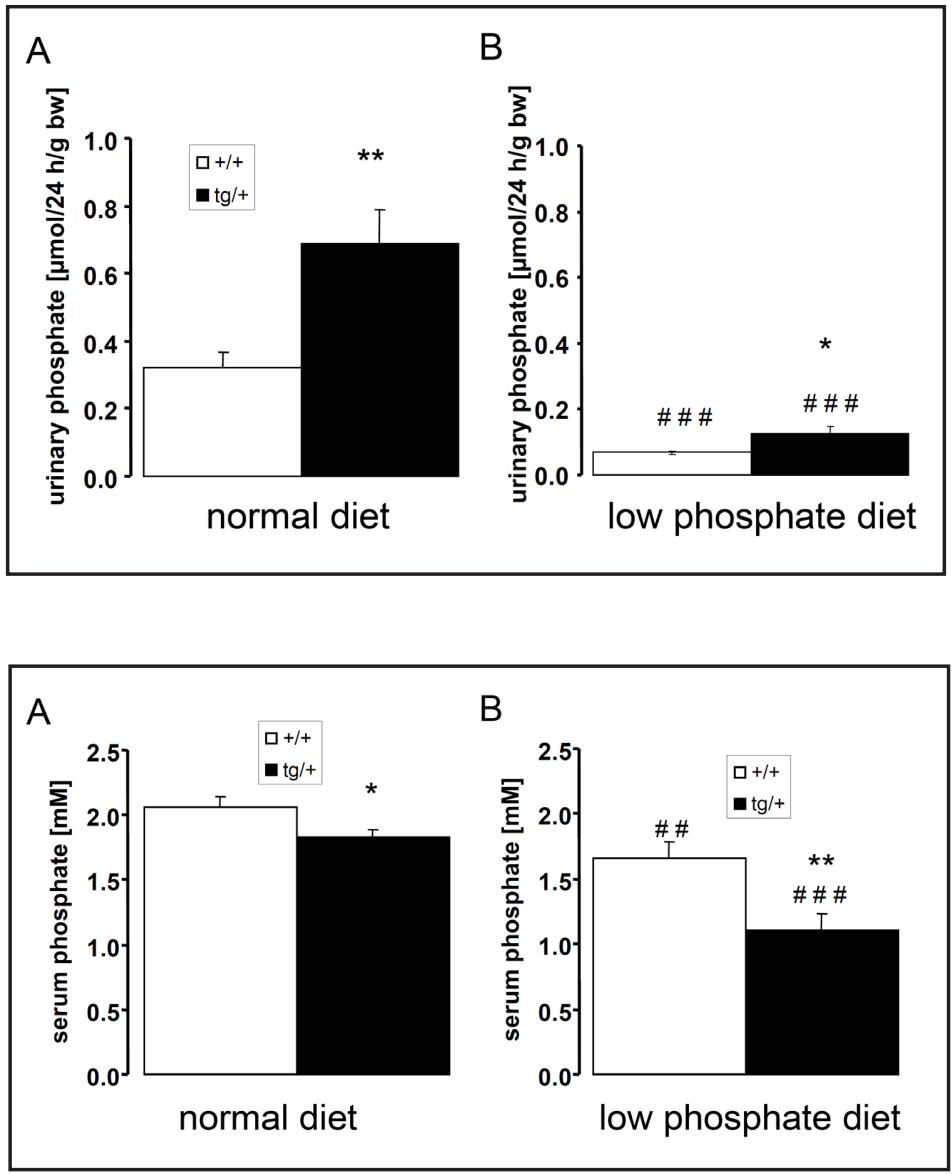

In order to elucidate the in vivo significance of OSR1-sensitive renal tubular phosphate transport, experiments were performed in OSR1 knockin mice (osr $\left.1^{t / /+}\right)$, which were heterozygously carrying a WNK-insensitive ${ }^{\mathrm{T} 185 \mathrm{~A}} \mathrm{OSR} 1 \mathrm{mutant}$. The animals were compared to respective wild type mice $\left(o s r 1^{+/+}\right)$. On a standard diet, urinary phosphate excretion was significantly higher in $o s r 1^{t g /+}$ mice than in $o s r 1^{+/+}$mice (Fig. 3A). A low-phosphate diet decreased the urinary phosphate excretion in both, osr $1^{\text {tg/+ }}$ and $o s r 1^{+/+}$mice (Fig. 3B). During the low-phosphate-diet, however, urinary phosphate excretion was still significantly higher in $o s r 1^{/ t g /+}$ mice than in $o s r 1^{+/+}$mice (Fig. 3B). Urinary calcium excretion tended to be lower in osr $1^{\mathrm{tg} / \mathrm{+}}$ mice $(0.24 \pm 0.06 \mu \mathrm{mol} / 24 \mathrm{~h} / \mathrm{g} \mathrm{BW}, \mathrm{n}=8)$ than in $o s r 1^{+/+}$mice $(0.17 \pm 0.03 \mu \mathrm{mol} / 24 \mathrm{~h} / \mathrm{g}$ $\mathrm{BW}, \mathrm{n}=10$ ), a difference, however, not reaching statistical significance.

In theory, the phosphaturia of osr $1^{\text {tg/+ }}$ mice could have been due to an increased serum phosphate concentration. Conversely, phosphaturia due to decreased renal tubular phosphate transport should result in a decrease of serum phosphate concentration. Thus, serum phosphate concentration was determined. As illustrated in Fig. 4A, the serum phosphate concentration was significantly lower in $o s r 1^{t g /+}$ mice than in $o s r 1^{+/+}$mice. Thus, the phosphaturia of $\operatorname{osr} 1^{\text {tg/+ }}$ mice was not due to hyperphosphatemia but obviously resulted in hypophosphatemia. Dietary phosphate depletion decreased the serum phosphate concentration in both, osr $1^{\text {tg/+ }}$ mice and in $o s r 1^{+/+}$mice and further enhanced the difference between the genotypes (Fig. 4B). Serum calcium levels were similar in $o s r 1^{+/+}$mice $(2.38 \pm$ $0.05 \mathrm{mM}, \mathrm{n}=8)$ and $o s r 1^{\mathrm{tg} / \mathrm{t}}$ mice $(2.41 \pm 0.04 \mathrm{mM}, \mathrm{n}=10)$. To study whether the partial OSR1 


\section{Kidney \\ Blood Pressure \\ Research}

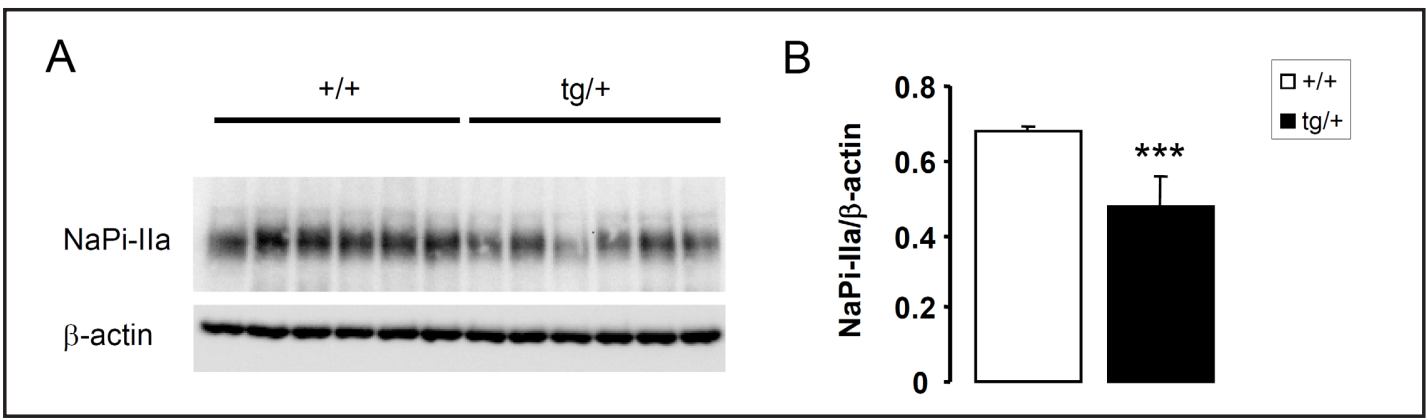

Fig. 5. Protein abundance of renal sodium-dependent phosphate cotransporter NaPiIla in the brush border membrane in kidneys from osr $1^{+/+}$and $o s r 1^{t g /+}$ mice. A. Western blot for NaPiIla. The membrane was stripped and reprobed for $\beta$-actin to control for loading. Densitometry was performed and the ratio of the protein of interest over $\beta$-actin calculated. B. Bar graphs present data as arithmetic means \pm SEM $(\mathrm{n}=10)$. *** indicates significant difference from osr $1^{+/+}$mice (Student's t-test, $\mathrm{p}<0.001$ ).

deficiency results in lower apical expression of NaPiIIa, BBMVs from the proximal tubule were retrieved and NaPiIla protein expression determined. As shown in Fig. 5, BBMVs from osr $1^{\text {tg/+ }}$ mice indeed expressed NaPilla to a significantly lesser extent than BBMVs from osr $1^{+/+}$mice.

At least in theory, the decreased renal tubular phosphate transport could have resulted from altered hormone levels. Thus, the serum concentration of parathyroid hormone (PTH), calcitriol $\left(1,25(\mathrm{OH})_{2} \mathrm{D}_{3}\right)$, and fibroblast growth factor 23 (FGF23) were determined. As shown in Fig. 6, the serum concentrations of PTH (Fig. 6A) and of $1,25(\mathrm{OH})_{2} \mathrm{D}_{3}$ (Fig. 6B) were similar in $o s r 1^{t g /+}$ mice and in $o s r 1^{+/+}$mice. The serum FGF23 concentration was, however, significantly higher in $o s r 1^{\text {tg/+ }}$ mice than in $o s r 1^{+/+}$mice (Fig. 6C). Dietary phosphate depletion resulted in a significant increase in the $1,25(\mathrm{OH})_{2} \mathrm{D}_{3}$ concentration of both, osr $1^{\text {tg/t }}$ mice and $o s r 1^{+/+}$mice and tended to decrease the serum concentrations of PTH and FGF23, effects, however not reaching statistical significance (Fig. 6).

As FGF23 signaling depends on Klotho, additional experiments were performed to elucidate whether partial OSR deficiency modifies renal Klotho expression. To this end, renal Klotho protein was determined in $o s r 1^{1 g /+}$ mice and $o s r 1^{+/+}$mice (Fig. 7). As a result, no significant difference of Klotho protein abundance could be observed between osr $^{\text {tg/t+ }}$ mice and $o s r 1^{+/+}$mice.

\section{Discussion}

The present observations reveal that the oxidative stress-responsive kinase 1 (OSR1) is expressed in proximal renal tubules and stimulates renal tubular phosphate transport. To the best of our knowledge OSR1 expression in proximal renal tubules has not been shown before. We further demonstrate that WNK resistance of OSR1 led to phosphaturia. Accordingly, renal tubular phosphate reabsorption was decreased and thus renal phosphate excretion increased in OSR1 knockin mice carrying one allele of the WNK-insensitive ${ }^{\mathrm{T} 185 \mathrm{~A}}$ OSR1 mutant $\left(o s r 1^{t g /+}\right)$ as compared to the respective wild type mice (osr $\left.1^{+/+}\right)$.

The electrophysiological recordings with the two-electrode voltage clamp technique in Xenopus oocytes heterologously expressing NaPiIIa with and without OSR1 pointed to a stimulatory effect of OSR1 on NaPiIIa activity. Along those lines, partial deficiency of OSR1 activity in $\operatorname{osr} 1^{t g /+}$ mice led to lower NaPiIIa surface abundance in brush border membrane vesicles iolated from the proximal tubule. The observations in the oocytes suggest that OSR1 directly stimulates NaPiIIa and thus influences renal phosphate excretion. The phosophaturia may, however, reflect in part other mechansims. 


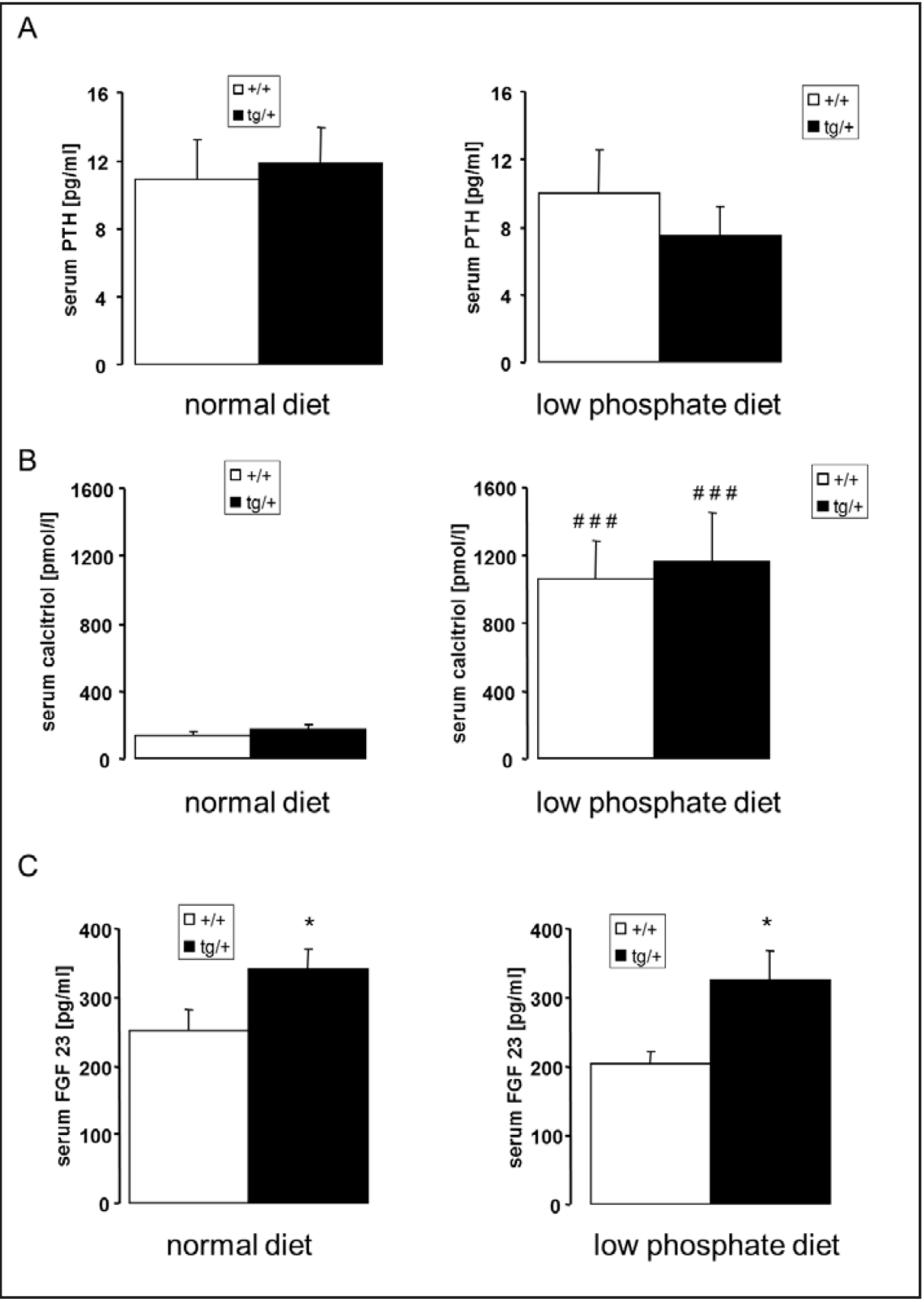

Fig. 6. Serum concentration of PTH, $1,25(\mathrm{OH})_{2} \mathrm{D}_{3}$, and FGF23 in $o s r 1^{+/+}$and $o s r 1^{\mathrm{tg} /+}$ mice. Arithmetic means \pm SEM $(n=8-11)$ of serum PTH $(A), 1,25(\mathrm{OH})_{2} \mathrm{D}_{3}(\mathrm{~B})$, and FGF23 (C) in osr $1^{+/+}$mice (white bars) and osr $1^{\text {tg/+ }}$ mice (black bars) under normal diet (left bars) and following dietary phosphate depletion (right bars). ${ }^{*}(\mathrm{p}<0.05)$ indicates significant difference from $o s r 1^{+/+}$mice, \#\#\# ( $\left.<<0.001\right)$ indicates significant difference from normal diet.

The phosphaturia of $o s r 1^{\text {tg/+ }}$ mice was not secondary to an increased serum phosphate concentration, which was actually decreased. In theory, the phosphaturia $o s r 1^{t g /+}$ could result from an increased serum level of PTH, a hormone increasing urinary phosphate output by stimulation of internalization and subsequent degradation of NaPiIIa [30, 34]. The PTH serum concentration was, however, not significantly different between $\operatorname{osr}^{1 \mathrm{tg} /+}$ and 


\section{Kidney Blood Pressure Research}

Fig. 7. Abundance of Klotho protein in the kidneys from $o s r 1^{+/+}$and osr $1^{t g /+}$ mice. (A) Original Western blots and (B) arithmetic means \pm SEM ( $\mathrm{n}=10$ ) of the Klotho over GAPDH density ratio in $0 s r 1^{+/+}$mice (white bar) and osr1tg/+ mice (black bar).

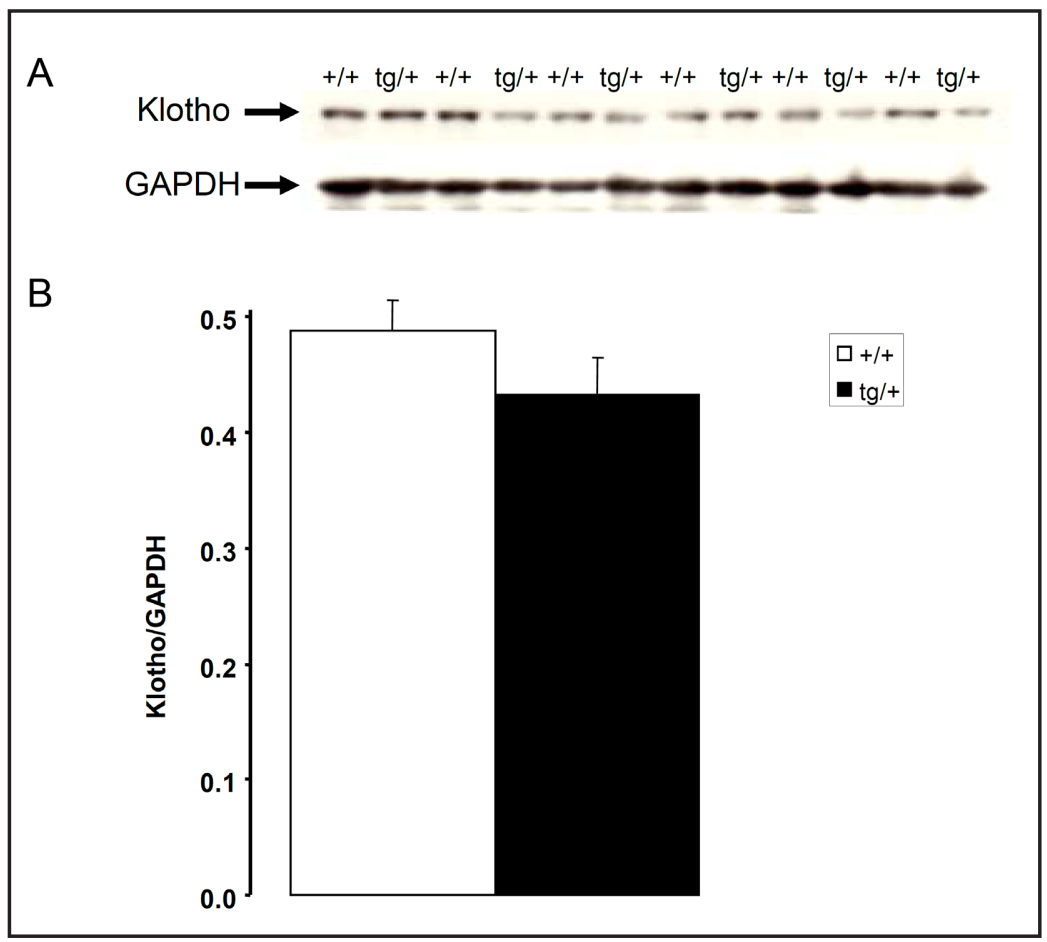

osr $1^{+/+}$mice. This observation does not rule out minor alterations of serum PTH levels. Renal tubular phosphate transport and serum phosphate concentration could further be modified by calcitriol $\left(1,25(\mathrm{OH})_{2} \mathrm{D}_{3}\right)$. The serum $1,25(\mathrm{OH})_{2} \mathrm{D}_{3}$ concentration was, however, again not significantly different between between $\operatorname{ssr} 1^{\text {tg/+ }}$ mice and $o s r 1^{+/+}$mice. The renal $1 \alpha$-hydroxylase and thus the formation of $1,25(\mathrm{OH})_{2} \mathrm{D}_{3}$ are stimulated by PTH [52] and by cellular phosphate depletion [53]. The present observations confirm the increase in serum $1,25(\mathrm{OH})_{2} \mathrm{D}_{3}$ following dietary phosphate depletion and confirm the decrease of urinary phosphate output in phosphate-depleted animals.

Our study further shows that the FGF23 serum concentration was higher in osr $1^{\text {tg/+ }}$ mice than in $0 s r 1^{+/+}$mice. FGF23 is known to be up-regulated by $1,25(\mathrm{OH})_{2} \mathrm{D}_{3}$ and in turn to decrease the formation of $1,25(\mathrm{OH}) 2 \mathrm{D}_{3}[54,55]$. In view of the serum $1,25(\mathrm{OH})_{2} \mathrm{D}_{3}$ levels, the slightly but significantly enhanced FGF23 serum level in $o s r 1^{\text {tg/+ }}$ mice cannot be explained by $1,25(\mathrm{OH})_{2} \mathrm{D}_{3}$-dependent stimulation of FGF23 expression.

FGF23 is secreted by osteocytes and decreases renal tubular phosphate transport [56]. The increased serum FGF23 concentrations could thus contribute to the phosphaturia of the $o s r 1^{t g /+}$ mice. Since FGF23 formation is stimulated by PTH, increased phosphate intake and hyperphosphatemia [57-59], the enhanced FGF23 serum level of $o s r 1^{\text {tg/+ }}$ mice cannot be explained by renal phosphate loss and hypophosphatemia. In theory, the enhanced FGF23 release in $o s r 1^{t g / t}$ mice could be secondary to the effect of OSR1 on $\mathrm{NaCl}$-co-transporter NCC. The carrier is expressed in osteoblasts, fosters bone differentiation and increases bone mineral density [23-25]. OSR1 activates and phosphorylates NCC [1-3, 9-14]. Alternatively, OSR1 could be effective through inhibition of renal NCC or by more directly modulating FGF23 release from osteocytes. Further studies are warranted addressing the mechanisms causing the elevated FGF23 plasma concentration in $o s r 1^{\mathrm{tg} / \mathrm{t}}$ mice .

The effect of FGF23 on renal cells requires expression of Klotho, which thus similarly influences phosphate homeostasis [38]. The determination of total renal Klotho protein expression did, however not reveal any significant differences between $\operatorname{osr} 1^{\mathrm{tg} / \mathrm{t}}$ mice and osr $1^{+/+}$mice.

At least in theory, OSR1 may be in part effective by regulating the thiazide-sensitive $\mathrm{Na}^{+}-\mathrm{Cl}^{-}$cotransporter and the furosemide-sensitive $\mathrm{Na}^{+}, \mathrm{K}^{+}, 2 \mathrm{Cl}^{-}$cotransporters (NKCC1 and 


\section{Kidney \\ Blood Pressure Research}

Pathare/Föller/Daryadel et al.: OSR1-Sensitive Pi Transport

NKCC2) $[13,60]$. Inhibition of NCC by thiazides is well known to cause phosphaturia [61] and anticalciuria [62]. Decreased stimulation of NCC in $o s r 1^{t g / t}$ bone cells may further contribute to or even account for the enhanced FGF23 plasma concentrations [63].

The OSR1 sensitivity of renal phosphate excretion and plasma phosphate concentration may have clinical implications for bone mineralization on the one hand [64] and vascular calcification on the other $[65,66]$. It is tempting to speculate that decreased OSR1 activity may foster demineralization of bone and enhanced OSR1 activity may predipose to phosphate retention and subsequent tissue calcification. However, calcification is an active process not only depending on plasma concentrations of $\mathrm{Ca}^{2+}$ and phosphate [67]. Thus, additional experimental effort is needed to elucidate the impact of OSR1 activity on mineral metabolism.

\section{Conclusion}

OSR1 participates in the regulation of FGF23 release and renal tubular phosphate transport. OSR1 stimulates NaPiIIa, and partial loss of OSR1 activity leads to phosphaturia and increased formation of FGF23. The present observations thus disclose a completely novel, powerful element in the regulation of mineral metabolism and a novel functional role of oxidative stress-responsive kinase 1.

\section{Conflict of Interests}

The authors declare that they have no competing financial interests to disclose.

\section{Acknowledgements}

The authors are indebted to Dario Alessi from the MRC Protein Phosphorylation Unit, College of Life Sciences, University of Dundee, Dundee, who kindly provided mice and the OSR1 antibody. They are further grateful to Akiko Saito from the Kyowa Hakko Kirin Co., Ltd., Japan, who provided the antibody against Klotho. The authors further gratefully acknowledge the meticulous preparation of the manuscript by L. Subasic. This work was supported by the Deutsche Forschungsgemeinschaft (DFG) and the Swiss National Center for Competence in Research NCCR Kidney.CH.

\section{References}

1 Delpire E, Gagnon KB: SPAK and OSR1: STE20 kinases involved in the regulation of ion homoeostasis and volume control in mammalian cells. Biochem J 2008;409:321-331.

-2 Kahle KT, Rinehart J, Lifton RP: Phosphoregulation of the Na-K-2Cl and K-Cl cotransporters by the WNK kinases. Biochim Biophys Acta 2010;1802:1150-1158.

-3 Richardson C, Alessi DR: The regulation of salt transport and blood pressure by the WNK-SPAK/OSR1 signalling pathway. J Cell Sci 2008;121:3293-3304.

-4 Salter RD, Watkins SC: Dendritic cell altered states: what role for calcium? Immunol Rev 2009;231:278-288.

-5 Solomon A, Bandhakavi S, Jabbar S, Shah R, Beitel GJ, Morimoto RI: Caenorhabditis elegans OSR-1 regulates behavioral and physiological responses to hyperosmotic environments. Genetics 2004;167:161-170.

6 Wheeler JM, Thomas JH: Identification of a novel gene family involved in osmotic stress response in Caenorhabditis elegans. Genetics 2006;174:1327-1336. 


\section{Kidney \\ Blood Pressure Research}

7 Vitari AC, Deak M, Morrice NA, Alessi DR: The WNK1 and WNK4 protein kinases that are mutated in Gordon's hypertension syndrome phosphorylate and activate SPAK and OSR1 protein kinases. Biochem J 2005;391:1724.

-8 Zagorska A, Pozo-Guisado E, Boudeau J, Vitari AC, Rafiqi FH, Thastrup J, Deak M, Campbell DG, Morrice NA, Prescott AR, Alessi DR: Regulation of activity and localization of the WNK1 protein kinase by hyperosmotic stress. J Cell Biol 2007;176:89-100.

-9 Richardson C, Sakamoto K, de los Heros P, Deak M, Campbell DG, Prescott AR, Alessi DR: Regulation of the NKCC2 ion cotransporter by SPAK-OSR1-dependent and -independent pathways. J Cell Sci 2011;124:789-800.

-10 Anselmo LB, Gross JL, Haddad F, Deheinzelin D, Younes RN, Barbuto JA: Functional analysis of cells obtained from bronchoalveolar lavage fluid (BALF) of lung cancer patients. Life Sci 2005;76:2945-2951.

11 Delpire E, Gagnon KB: SPAK and OSR1, key kinases involved in the regulation of chloride transport. Acta Physiol (Oxf) 2006;187:103-113.

12 Gimenez I: Molecular mechanisms and regulation of furosemide-sensitive Na-K-Cl cotransporters. Curr Opin Nephrol Hypertens 2006;15:517-523.

13 Huang CL, Yang SS, Lin SH: Mechanism of regulation of renal ion transport by WNK kinases. Curr Opin Nephrol Hypertens 2008;17:519-525.

14 Vitari AC, Thastrup J, Rafiqi FH, Deak M, Morrice NA, Karlsson HK, Alessi DR: Functional interactions of the SPAK/OSR1 kinases with their upstream activator WNK1 and downstream substrate NKCC1. Biochem J 2006;397:223-231.

-15 Flatman PW: Cotransporters, WNKs and hypertension: an update. Curr Opin Nephrol Hypertens 2008;17:186192.

16 Furgeson SB, Linas S: Mechanisms of type I and type II pseudohypoaldosteronism. J Am Soc Nephrol 2010;21:1842-1845.

17 Uchida S: Pathophysiological roles of WNK kinases in the kidney. Pflugers Arch 2010;460:695-702.

-18 Wilson FH, Disse-Nicodeme S, Choate KA, Ishikawa K, Nelson-Williams C, Desitter I, Gunel M, Milford DV, Lipkin GW, Achard JM, Feely MP, Dussol B, Berland Y, Unwin RJ, Mayan H, Simon DB, Farfel Z, Jeunemaitre X, Lifton RP: Human hypertension caused by mutations in WNK kinases. Science 2001;293:1107-1112.

19 Lin SH, Yu IS, Jiang ST, Lin SW, Chu P, Chen A, Sytwu HK, Sohara E, Uchida S, Sasaki S, Yang SS: Impaired phosphorylation of $\mathrm{Na}+\mathrm{K}+-2 \mathrm{Cl}$ - cotransporter by oxidative stress-responsive kinase-1 deficiency manifests hypotension and Bartter-like syndrome. Proc Natl Acad Sci U S A 2011;108:17538-17543.

20 Glover M, O'Shaughnessy KM: SPAK and WNK kinases: a new target for blood pressure treatment? Curr Opin Nephrol Hypertens 2011;20:16-22.

21 Villa F, Goebel J, Rafiqi FH, Deak M, Thastrup J, Alessi DR, van Aalten DM: Structural insights into the recognition of substrates and activators by the OSR1 kinase. EMBO Rep 2007;8:839-845.

22 Villa F, Deak M, Alessi DR, van Aalten DM: Structure of the OSR1 kinase, a hypertension drug target. Proteins 2008;73:1082-1087.

-23 Biber J, Hernando N, Forster I, Murer H: Regulation of phosphate transport in proximal tubules. Pflugers Arch 2009;458:39-52.

-24 Murer H, Forster I, Biber J: The sodium phosphate cotransporter family SLC34. Pflugers Arch 2004;447:763767.

-25 Villa-Bellosta R, Ravera S, Sorribas V, Stange G, Levi M, Murer H, Biber J, Forster IC: The Na+-Pi cotransporter PiT-2 (SLC20A2) is expressed in the apical membrane of rat renal proximal tubules and regulated by dietary Pi. Am J Physiol Renal Physiol 2009;296:F691-F699.

-26 Allon M: Effects of insulin and glucose on renal phosphate reabsorption: interactions with dietary phosphate. J Am Soc Nephrol 1992;2:1593-1600.

27 DeFronzo RA, Goldberg M, Agus ZS: The effects of glucose and insulin on renal electrolyte transport. J Clin Invest 1976;58:83-90.

28 Feld S, Hirschberg R: Insulinlike growth factor I and the kidney. Trends Endocrinol Metab 1996;7:85-93.

29 Jehle AW, Forgo J, Biber J, Lederer E, Krapf R, Murer H: IGF-I and vanadate stimulate Na/Pi-cotransport in OK cells by increasing type II Na/Pi-cotransporter protein stability. Pflugers Arch 1998;437:149-154.

30 Murer H, Hernando N, Forster I, Biber J: Proximal tubular phosphate reabsorption: molecular mechanisms. Physiol Rev 2000;80:1373-1409. 


\section{Kidney \\ Blood Pressure Research}

Kidney Blood Press Res 2012;36:149-161

\begin{tabular}{l|l}
\hline DOI: $10.1159 / 000343405$ & C 2012 S. Karger AG, Basel \\
\hline
\end{tabular}

Published online: October 26, 2012

www.karger.com/kbr

Pathare/Föller/Daryadel et al.: OSR1-Sensitive Pi Transport

-31 Nowik M, Picard N, Stange G, Capuano P, Tenenhouse HS, Biber J, Murer H, Wagner CA: Renal phosphaturia during metabolic acidosis revisited: molecular mechanisms for decreased renal phosphate reabsorption. Pflugers Arch 2008;457:539-549.

-32 Picard N, Capuano P, Stange G, Mihailova M, Kaissling B, Murer H, Biber J, Wagner CA: Acute parathyroid hormone differentially regulates renal brush border membrane phosphate cotransporters. Pflugers Arch 2010;460:677-687.

33 Bacic D, Schulz N, Biber J, Kaissling B, Murer H, Wagner CA: Involvement of the MAPK-kinase pathway in the PTH-mediated regulation of the proximal tubule type IIa Na+/Pi cotransporter in mouse kidney. Pflugers Arch 2003;446:52-60.

34 Bacic D, Lehir M, Biber J, Kaissling B, Murer H, Wagner CA: The renal Na+/phosphate cotransporter NaPi-IIa is internalized via the receptor-mediated endocytic route in response to parathyroid hormone. Kidney Int 2006;69:495-503.

35 Bhandaru M, Kempe DS, Rotte A, Capuano P, Pathare G, Sopjani M, Alesutan I, Tyan L, Huang DY, Siraskar B, Judenhofer MS, Stange G, Pichler BJ, Biber J, Quintanilla-Martinez L, Wagner CA, Pearce D, Foller M, Lang F: Decreased bone density and increased phosphaturia in gene-targeted mice lacking functional serum- and glucocorticoid-inducible kinase 3. Kidney Int 2011;80:61-67.

-36 Dermaku-Sopjani M, Sopjani M, Saxena A, Shojaiefard M, Bogatikov E, Alesutan I, Eichenmuller M, Lang F: Downregulation of NaPi-IIa and NaPi-IIb Na-coupled phosphate transporters by coexpression of Klotho. Cell Physiol Biochem 2011;28:251-258.

-37 Foller M, Kempe DS, Boini KM, Pathare G, Siraskar B, Capuano P, Alesutan I, Sopjani M, Stange G, Mohebbi N, Bhandaru M, Ackermann TF, Judenhofer MS, Pichler BJ, Biber J, Wagner CA, Lang F: PKB/SGK-resistant GSK3 enhances phosphaturia and calciuria. J Am Soc Nephrol 2011;22:873-880.

-38 Hu MC, Shi M, Zhang J, Pastor J, Nakatani T, Lanske B, Razzaque MS, Rosenblatt KP, Baum MG, Kuro-o M, Moe OW: Klotho: a novel phosphaturic substance acting as an autocrine enzyme in the renal proximal tubule. FASEB J 2010;24:3438-3450.

-39 Kempe DS, Dermaku-Sopjani M, Frohlich H, Sopjani M, Umbach A, Puchchakayala G, Capasso A, Weiss F, Stubs M, Foller M, Lang F: Rapamycin-induced phosphaturia. Nephrol Dial Transplant 2010;25:2938-2944.

-40 Kempe DS, Ackermann TF, Boini KM, Klaus F, Umbach AT, Dermaku-Sopjani M, Judenhofer MS, Pichler BJ, Capuano P, Stange G, Wagner CA, Birnbaum MJ, Pearce D, Foller M, Lang F: Akt2/PKBbeta-sensitive regulation of renal phosphate transport. Acta Physiol (Oxf) 2010;200:75-85.

41 Busch AE, Wagner CA, Schuster A, Waldegger S, Biber J, Murer H, Lang F: Properties of electrogenic Pi transport by a human renal brush border Na+/Pi transporter. J Am Soc Nephrol 1995;6:1547-1551.

-42 Rexhepaj R, Dermaku-Sopjani M, Gehring EM, Sopjani M, Kempe DS, Foller M, Lang F: Stimulation of electrogenic glucose transport by glycogen synthase kinase 3. Cell Physiol Biochem 2010;26:641-646.

43 Bohmer C, Sopjani M, Klaus F, Lindner R, Laufer J, Jeyaraj S, Lang F, Palmada M: The serum and glucocorticoid inducible kinases SGK1-3 stimulate the neutral amino acid transporter SLC6A19. Cell Physiol Biochem 2010;25:723-732.

-44 Eckey K, Strutz-Seebohm N, Katz G, Fuhrmann G, Henrion U, Pott L, Linke WA, Arad M, Lang F, Seebohm G: Modulation of human ether a gogo related channels by CASQ2 contributes to etiology of catecholaminergic polymorphic ventricular tachycardia (CPVT). Cell Physiol Biochem 2010;26:503-512.

-45 Rafiqi FH, Zuber AM, Glover M, Richardson C, Fleming S, Jovanovic S, Jovanovic A, O'Shaughnessy KM, Alessi DR: Role of the WNK-activated SPAK kinase in regulating blood pressure. EMBO Mol Med 2010;2:63-75.

-46 Vallon V: In vivo studies of the genetically modified mouse kidney. Nephron Physiol 2003;94:1-5.

47 Biber J, Stieger B, Haase W, Murer H: A high yield preparation for rat kidney brush border membranes. Different behaviour of lysosomal markers. Biochim Biophys Acta 1981;647:169-176.

48 Biber J, Stieger B, Stange G, Murer H: Isolation of renal proximal tubular brush-border membranes. Nat Protoc 2007;2:1356-1359.

49 Custer M, Lotscher M, Biber J, Murer H, Kaissling B: Expression of Na-P(i) cotransport in rat kidney: localization by RT-PCR and immunohistochemistry. Am J Physiol 1994;266:F767-F774.

50 Bachmann S, Schlichting U, Geist B, Mutig K, Petsch T, Bacic D, Wagner CA, Kaissling B, Biber J, Murer H, Willnow TE: Kidney-specific inactivation of the megalin gene impairs trafficking of renal inorganic sodium phosphate cotransporter (NaPi-IIa). J Am Soc Nephrol 2004;15:892-900. 


\section{Kidney \\ Blood Pressure Research}

Pathare/Föller/Daryadel et al.: OSR1-Sensitive Pi Transport

-51 Nedvetsky PI, Tabor V, Tamma G, Beulshausen S, Skroblin P, Kirschner A, Mutig K, Boltzen M, Petrucci O, Vossenkamper A, Wiesner B, Bachmann S, Rosenthal W, Klussmann E: Reciprocal regulation of aquaporin-2 abundance and degradation by protein kinase A and p38-MAP kinase. J Am Soc Nephrol 2010;21:1645-1656.

52 Portale AA, Miller WL: Human 25-hydroxyvitamin D-1alpha-hydroxylase: cloning, mutations, and gene expression. Pediatr Nephrol 2000;14:620-625.

53 Perwad F, Azam N, Zhang MY, Yamashita T, Tenenhouse HS, Portale AA: Dietary and serum phosphorus regulate fibroblast growth factor 23 expression and 1,25-dihydroxyvitamin D metabolism in mice. Endocrinology 2005;146:5358-5364.

54 Razzaque MS, Lanske B: The emerging role of the fibroblast growth factor-23-klotho axis in renal regulation of phosphate homeostasis. J Endocrinol 2007;194:1-10.

55 Tang WJ, Wang LF, Xu XY, Zhou Y, Jin WF, Wang HF, Gao J: Autocrine/paracrine action of vitamin D on FGF23 expression in cultured rat osteoblasts. Calcif Tissue Int 2010;86:404-410.

-56 Amatschek S, Haller M, Oberbauer R: Renal phosphate handling in human--what can we learn from hereditary hypophosphataemias? Eur J Clin Invest 2010;40:552-560.

57 Lavi-Moshayoff V, Wasserman G, Meir T, Silver J, Naveh-Many T: PTH increases FGF23 gene expression and mediates the high-FGF23 levels of experimental kidney failure: a bone parathyroid feedback loop. Am J Physiol Renal Physiol 2010;299:F882-F889.

58 Vervloet MG, van Ittersum FJ, Buttler RM, Heijboer AC, Blankenstein MA, ter Wee PM: Effects of dietary phosphate and calcium intake on fibroblast growth factor-23. Clin J Am Soc Nephrol 2011;6:383-389.

-59 Wolf M: Forging forward with 10 burning questions on FGF23 in kidney disease. J Am Soc Nephrol 2010;21:1427-1435.

60 Richardson C, Rafiqi FH, Karlsson HK, Moleleki N, Vandewalle A, Campbell DG, Morrice NA, Alessi DR: Activation of the thiazide-sensitive Na+-Cl- cotransporter by the WNK-regulated kinases SPAK and OSR1. J Cell Sci 2008;121:675-684.

61 Winaver J, Teredesai P, Anast C, Puschett JB: Investigations into the mechanism of the phosphaturia induced by chlorothiazide. J Pharmacol Exp Ther 1981;218:46-54.

62 Nijenhuis T, Vallon V, van der Kemp AW, Loffing J, Hoenderop JG, Bindels RJ: Enhanced passive Ca2+ reabsorption and reduced Mg2+ channel abundance explains thiazide-induced hypocalciuria and hypomagnesemia. J Clin Invest 2005;115:1651-1658.

-63 Dvorak MM, De Joussineau C, Carter DH, Pisitkun T, Knepper MA, Gamba G, Kemp PJ, Riccardi D: Thiazide diuretics directly induce osteoblast differentiation and mineralized nodule formation by interacting with a sodium chloride co-transporter in bone. J Am Soc Nephrol 2007;18:2509-2516.

64 Bonjour JP: Calcium and phosphate: a duet of ions playing for bone health. J Am Coll Nutr 2011;30:438S-448S.

-65 Ellam TJ, Chico TJ: Phosphate: the new cholesterol? The role of the phosphate axis in non-uremic vascular disease. Atherosclerosis 2012;220:310-318.

-66 Kendrick J, Chonchol M: The role of phosphorus in the development and progression of vascular calcification. Am J Kidney Dis 2011;58:826-834.

67 Shao JS, Cheng SL, Sadhu J, Towler DA: Inflammation and the osteogenic regulation of vascular calcification: a review and perspective. Hypertension 2010;55:579-592. 